\title{
PENGEMBANGAN MODUL BARISAN DAN DERET BERBASIS KONSTEKSTUAL
}

\author{
Tri Candra Wulandari \\ Universitas Kanjuruhan Malang \\ fikri.chan@unikama.ac.id
}

\begin{abstract}
Abstrak
Penelitian ini bertujuan untuk mengembangkan modul barisan deret untuk siswa SMK program pariwisata. Pengembangan modul matematika pada materi Barisan dan Deret ini ditujukan pada siswa dan guru dengan harapan siswa dapat melaksanakan pembelajaran sesuai dengan kecepatan belajar siswa (mastery learning). Modul yang dikembangkan disesuaikan dengan masalah-masalah yang sering dihadapi di dunia pariwisata. Penelitian pengembangan dilakukan dalam tiga fase yaitu: (1) penelitian awal (preliminary research), (2) fase pengembangan (prototyping phase), dan (3) fase penilaian (assessment phase). Berdasarkan hasil validasi, modul yang dikembangkan merupakan modul yang telah di validasi sebanyak 2 (dua) tahap. Perolehan skor rata-rata keseluruhan aspek adalah 3,58. Menurut kriteria kevalidan yang telah ditetapkan, maka modul dapat dikatakan valid yang berarti modul tersebut layak digunakan.
\end{abstract}

Kata kunci: pengembangan modul, kontekstual, barisan dan deret

\begin{abstract}
The purpose of this research is to develop module Series and Sequence for student of tourism program at vocational high school. The development of mathematics modules in sequence and series is directed to students and teachers, hope that students can carry out the study in accordance with mastery learning. Modules developed appropriate to the problems that are often encountered in the world of tourism. This research develop in three phases, there are: preliminary research, prototyping phase and assessment phase. Based from validation score, contextual module has average score overall 3.58. According to the validity of the criteria that has been set, then the module can be said to be valid, which means the module is fit for use.
\end{abstract}

Keywords: developing modules, contextual, sequence and series

\section{PENDAHULUAN}

Siswa SMK memiliki latar belakang kognitif yang berbeda dengan siswa SMA. Siswa yang memilih di SMK tidak hanya berharap dapat mengikuti pendidikan jenjang menengah, akan tetapi dapat memiliki ketrampilan sehingga ia mampu bekerja setelah lulus SMK. Sesuai dengan struktur kurikulum di SMK, pembelajaran di sekolah tidak murni dilaksanakan selama 3 tahun berada di sekolah, artinya karena siswa harus melaksanakan praktik kerja industri (Prakerin) selama kurang lebih satu semester atau 6 bulan. Selama prakerin, siswa murni melaksanakan kegiatan praktik kerja sesuai bidangnya, apabila siswa mengambil program pariwisata, maka ia akan melaksanakan praktik di bidang pariwisata, seperti di Jatim Park, menjadi staf di penjualan tiket penerbangan atau di perusahaan tour dan travel. Selama 6 bulan ini pula siswa tidak berada di sekolah dengan kata lain, siswa tidak mengikuti kegiatan pembelajaran di sekolah. 
Sedangkan materi pembelajaran dimampatkan saat siswa berada di kelas X (sepuluh) kelas XI (sebelas) saat siswa akan berangkat prakerin dan kelas XII (dua belas).

Melihat kondisi pembelajaran ini, pembelajaran matematika sebaiknya lebih meningkatkan variasi dalam menerapkan strategi untuk mengoptimalkan kemampuan siswa (Sutama,2013). Peneliti berkeinginan untuk mengembangkan modul matematika dengan tujuan siswa dan guru dapat melaksanakan pembelajaran sesuai dengan kecepatan belajar siswa (mastery learning). Dengan modul siswa dapat mencapai dan menyelesaikan bahan belajarnya dengan belajar secara individual. Peserta belajar tidak dapat melanjutkan ke suatu unit pelajaran berikutnya sebelum menyelesaikan secara tuntas materi belajarnya. Dengan modul siswa dapat mencapai dan menyelesaikan bahan belajarnya dengan belajar secara individual. Peserta belajar tidak dapat melanjutkan ke suatu unit pelajaran berikutnya sebelum menyelesaikan secara tuntas materi belajarnya. Dengan modul siswa dapat mengontrol kemampuan dan intensitas belajarnya. Dalam pembelajaran individual, modul memiliki peran (1) sebagai media utama dalam proses pembelajaran, (2) alat yang digunakan untuk menyusun dan mengawasi proses siswa memperoleh informasi, (3) penunjang media pembelajaran individual lainnya. (Belawati, 2003; Wulandari, 2012).

Penulisan modul bertujuan untuk: (1) memperjelas dan mempermudah penyajian pesan agar tidak terlalu bersifat verbal, (2) mengatasi keterbatasan waktu, ruang, dan daya indera, baik siswa atau peserta diklat maupun guru atau instruktur, (3) dapat digunakan secara tepat dan bervariasi, seperti: (i) meningkatkan motivasi dan gairah belajar bagi siswa atau peserta diklat, (ii) mengembangkan kemampuan peserta didik dalam berinteraksi langsung dengan lingkungan dan sumber belajar lainnya, (iii) memungkinkan siswa atau peserta diklat belajar mandiri sesuai kemampuan dan minatnya, (iv) memungkinkan siswa atau peserta diklat dapat mengukur atau mengevaluasi sendiri hasil belajarnya (Dikmenjur, 2003;Wulandari,2012).

Modul yang dikembangkan merupakan modul matematika pada pokok bahasan barisan dan deret pada program keahlian pariwisata. Modul yang dikembangkan bercirikan kontekstual, yang disesuaikan dengan masalah-masalah pariwisata yang dikaitkan dengan konsep barisan dan deret. Seperti, pemberian masalah tentang penjualan tiket wisata yang kenaikannya membentuk barisan aritmatika, menghitung income yang akan diterima oleh pemilik usaha travel apabila hasil penjualan tiket membentuk deret aritmatik, dengan menggunakan modul bercirikan kontekstual ini siswa dapat beraktifitas secara signifikan yang membantu mereka dalam menghubungkan studi akademik dengan konteksnya dalam situasi kehidupan nyata, artinya baik materi ataupun soal-soal di dalam modul yang dituliskan dikaitkan dengan kehidupan sehari-hari (Danuri, 2014).

Karakteristik modul yang dikembangkan berbasis kontekstual, artinya modul disesuaikan dengan konteks kepariwisataan. Isi modul yang dikembangkan disesuaikan dengan ranah kontekstual yaitu (1) melakukan hubungan yang bermakna (making meaningful connections), (2) Melakukan pekerjaan atau kegiatan-kegiatan yang signifikan (doing significant work), (3) 
Belajar yang diatur sendiri (self regulated learning), (4) Bekerja sama (collaborating), (5) Berpikir kritis dan kreatif (critical \& creative thinking), (6) Memelihara atau membina pribadi (nurturingthe individual), (7) Mencapai standar yang tinggi (reaching high standards), (8) Penilaian yang sesungguhnya (authentic assessment). (Johnson, 2008:56)

\section{Spesifikasi modul yang dikembangkan}

Spesifikasi modul yang dikembangkan adalah (1) modul disesuaikan dengan kompetensi dasar (KD) yang mengacu pada kurikulum 2013 bidang studi Matematika SMK materi Barisan dan Deret untuk siswa kelas XI program keahlian Usaha Perjalanan Wisata (UPW), (2) pada awal materi dilengkapi peta konsep, (3) memuat masalah-masalah yang kontekstual, dalam hal ini soal barisan dan deret yang dibuat disesuaikan dengan keahlian UPW, seperti masalah penjualan tiket, menenetukan banyaknya wisatawan dan menghitung besar keuntugan yang diperoleh menggunakan konsep barisan dan deret, (4) modul yang dikembangkan merupakan modul cetak berbentuk bookfold, (5) Komponenkomponen yang tersedia dalam modul pembelajaran ini yaitu (a) bagian pendahuluan, (b) bagian Kegiatan Belajar, (c) Latihan, (d) Uji Kompetensi, (e) daftar pustaka dan (f) Glosarium, (6) modul yang dihasilkan merupakan hasil kajian dari pustaka yang relevan dan divalidasi oleh ahli sesuai bidangnya.

\section{Pentingnya Pengembangan}

Pengembangan modul Matematika pada materi Barisan dan Deret untuk siswa kelas XI SMK program keahlian UPW penting dikembangkan dengan alasan:

1. Sebagai salah satu sumber belajar yang dapat digunakan untuk belajar secara mandiri,

2. Modul matematika dengan karakteristik kontekstual yang mengacu pada kompetensi keahlian belum pernah dikembangkan,

3. Membantu siswa dalam belajar dan mengarah pada kemampuan belajar mandiri,

4. Membantu guru dalam penyampaian materi dan masalah-masalah berkaitan dengan pariwisata

\section{Prosedur Pengembangan}

Penelitian ini merupakan penelitian pengembangan. Penelitian pengembangan ini menggunakan model yang dikembangkan oleh Plomp. Berdasarkan langkah Plomp (15: 2010), maka pengembangan ini dilakukan dalam tiga fase yaitu: (1) penelitian awal (preliminary research), (2) fase pengembangan (prototyping phase), dan (3) fase penilaian (assessment phase).

Pertama, fase penelitian awal. Pada tahap penelitian awal peneliti melakukan analisis kondisi pembelajaran di kelas melalui pengamatan langsung dan mengumpulkan informasi yang diperoleh dari hasil wawancara dengan guru matematika dan siswa di SMK Negeri 2 Malang. Peneliti melakukan pengamatan langsung terhadap proses belajar mengajar di kelas, kondisi lingkungan di SMK Negeri 2 Malang saat pembelajaran berlangsung maupun saat istirahat. (a) berdasarkan hasil analisis pembelajaran di kelas, siswa mulai tidak fokus mengikuti pelajaran saat guru mulai membahas materi, artinya guru belum 
memunculkan lingkungan belajar hal ini dapat disebabkan oleh beberapa faktor diantaranya adalah pola pembelajaran yang kurang menarik yaitu guru hanya meminta siswa membuka buku halaman tertentu dan guru melakukan pembelajaran dengan teacher center bukan student center, materi yang disampaikan tidak diawali dengan menggali rasa ingin tahu siswa, guru tidak memberikan masalah yang mampu membuat siswa berfikir dan berpendapat. (b) berdasarkan wawancara dengan guru, diperoleh informasi bahwa guru sudah merasakan zona nyaman, karena siswa tidak ramai dan materi segera selesai. Akan tetapi hal ini tidak terlalu baik bagi siswa. Karena, siswa tidak dibiasakan untuk berfikir, mengetahui proses memperoleh suatu jawaban. Siswa tidak akan tahu rasanya apa itu rasa ingin tahu, yang membuat siswa menjadi lebih banyak membaca atau bertanya. Selain itu, guru tidak pernah membuat bahan ajar sesuai dengan karakteristik siswa. Selain itu, guru juga enggan untuk menyusun buku, LKS atau modul dikarenakan waktu yang terbatas. Menurut pengamatan peneliti, iklim dan suasana di sekolah mempengaruhi tingkat kreativitas guru. Kurangnya motivasi untuk berkarya adalah salah satu faktor penyebab guru enggan untuk menulis. Selain itu, kondisi guru yang sudah PNS membuat guru malas berusaha, guru lebih memilih buku yang instan, karena terdorong oleh faktor tidak mau repot. Perubahan mindset guru untuk selalu berkarya merupakan hal penting, agar guru mau berinovasi.

Kedua, fase pengembangan. Modul yang dikembangkan terdiri atas : (1) Bagian Pendahuluan yang berisi uraian singkat mengenai materi yang akan dijelaskan dalam modul, hubungan dengan materi sebelumnya, tujuan, peralatan dan waktu yang digunakan dalam mempelajari modul, dorongan belajar dan lain-lain. (2) Bagian utama, berisi uraian, contoh-contoh, ilustrasi, diagram, latihan dan umpan balik. (3) Bagian Penutup, berisi rangkuman atau kesimpulan, penjelasan tentang hubungan dengan materi selanjutnya, dan dorongan kepada peserta diklat karena berhasil menyelesaikan modul dan diminta mengikuti tes. Setelah outline selesai dibuat, peneliti akan mulai menulis draft I modul yang dikembangkan dengan memperhatikan outline/rancangan modul. Draft I yang telah jadi kemudian di review oleh ahli untuk memperoleh perbaikan-perbaikan sehingga menjadi draft II. Perbaikan draft I dapat berupa peninjauan kembali tentang kejelasan kalimat, kemenarikan tata letak, contoh dan gambar-gambar, umpan balik dan kesesuaian waktu bagi peserta diklat dalam melakukan aktivitas/ melaksanakan tugas.

Selain menghasilkan modul yang sudah siap diuji valid tidaknya oleh para ahli, pada tahap ini juga dihasilkan instrumen penilaian. Instrumen penilaian merupakan alat yang akan digunakan untuk melakukan evaluasi terhadap kriteria kualitas modul yang dikembangkan.

Ketiga, fase penilaian. Pada fase ini, modul yang telah selesai divalidasi oleh ahli kemudian dilakukan uji coba terhadap penggunaan modul. Berikut ini dipaparkan tentang hasil validasi dan hasil uji coba modul. Pada lembar validasi bahan ajar terdiri dari lima aspek, yaitu: (1) isi bahan ajar, (2) kesesuaian modul karakteristik kontekstual , (3) bahasa, (4) grafis, (5) manfaat bahan ajar. Setelah melakukan validasi, selanjutnya modul di uji coba 
kepada siswa. Uji coba dilaksanakan dalam dua tahap, yaitu uji coba kelompok kecil dan uji coba lapangan. Untuk menentukan kriteria kevalidan, interval ini dibagi menjadi tiga sub interval yang sama, yaitu: $1 \leq x<2, \quad 2 \leq x<3, \quad$ dan $3 \leq x \leq 4$. Kriteria kavalidan diguakan untuk menentukan valid atau tidaknya modul, , lembar observasi, dan angket yang ditetapkan sebagai berikut.

\section{Tabel 1. Kriteria Kevalidan}

\begin{tabular}{cl}
\hline Interval & Kriteria \\
\hline $1 \leq x<2$ & Tidak valid \\
\hline $2 \leq x<3$ & Cukup valid \\
\hline $3 \leq x \leq 4$ & Valid \\
\hline
\end{tabular}

Sumber: Suryaningsih (2011:47)

\section{HASIL PENGEMBANGAN DAN PEMBAHASAN}

Modul yang dikembangkan adalah modul dengan ciri kontekstual. Sesuai dengan kajian tentang konsep kontekstual, maka modul yang dikembangkan memiliki karakteristik sebagai berikut.

Sampul, Sampul depan menggunakan warna dasar orange, yang disesuaikan dengan warna program keahlian. Di sisi kiri terdapat kotak-kotak berbeda warna yang menunjukkan pola yang konsisten. Pada halaman sampul tidak terlalu banyak gambar, karena disesuaikan dengan ranah kognitif SMK yang memasuki tahap abstrak.

Pendahuluan, pada bagian pendahuluan, berisi deskripsi tentang materi, standar kompetensi, kompetensi dasar dan Indikator pencapaian.

Kegiatan Belajar 1, kegiatan belajar 1 membahas tentang Barisan dan Deret Aritmatika. Berisi pola barisan dan deret aritmatika. Definisi barisan aritmatika dan deret aritmatika. Kegiatan belajar I juga dilengkapi dengan contoh soal dan soal latihan. Contoh soal berkaitan langsung dengan masalah-masalah dalam pariwisata. Masalah yang diberikan berupa soal cerita yang berkaitan dengan pariwisata. Setelah masalah disampaikan, diberikan langkahlangkah pembahasan yang dilengkapi dengan alasan-alasan penggunaan konsep dalam menyelesaikan masalah.

Kegiatan Belajar 2, kegiatan belajar 2 membahas tentang Barisan dan Deret Geometri. Berisi pola barisan dan deret geometri. Definisi barisan geometri dan deret geometri. Sama halnya dengan kegiatan belajar 1, kegiatan belajar 2 juga dilengkapi dengan contoh soal dan soal latihan yang berupa masalah-masalah yang berkaitan dengan pariwisata.

Uji kompetensi, uji kompetensi berisi soal-soal tentang barisan aritmatika, deret aritmatika, barisan geometri dan deret geometri. Uji kompetensi ini bertujuan untuk melihat tingkat pemahaman terhadap isi modul.

Daftar Pustaka, berisi sumber bacaan utama pengembang dalam menulis dan mengembangkan isi modul.

Glosarium, berisi kosakata atau istilah-istilah yang dianggap sulit beserta maknanya agar tidak menimbulkan kesalahan makna.

Modul yang dikembangkan merupakan modul yang telah di validasi. Validasi draft modul dilaksanakan sebanyak 2 tahap. Hal ini berarti modul mengalami revisi sebanyak tiga kali atau menjadi 2 draft. Draft modul yang digunakan merupakan modul hasil pengembangan dari draft kedua setelah di validasi. Revisi pada draft I terkait pada isi modul yaitu: (1) penggunaan bahasa pada penyampaian masalah kontekstual 
Jurnal Inspirasi Pendidikan

Universitas Kanjuruhan Malang

yang berkaitan dengan pariwisata, (2) penulisan sumber gambar, (3) terdapat kesalahan pengetikan pada halaman 8,13 , 15 dan 20, dan (4) terdapat soal pada uji kompetensi yang tidak memiliki jawaban. Setelah dilakukan revisi, hasil validasi yang diperoleh adalah skor rata-rata keseluruhan aspek adalah 3,58. Menurut kriteria kevalidan yang telah ditetapkan, maka modul dapat dikatakan valid yang berarti modul tersebut layak digunakan.

Uji coba dilakukan pada siswa kelas XI UPW 2 SMK Negeri 2 Malang. Uji coba dilakukan sebanyak empat kali pertemuan, tiga kali pembelajaran dan sekali untuk tes penguasaan bahan ajar dengan jumlah 30 siswa. Pelaksanaan uji coba ini melibatkan dua orang observer. Dari hasil tes siswa pada uji lapangan, diperoleh hasil $85,3 \%$ siswa memperoleh skor lebih dari 80. Hal ini berarti modul dapat digunakan oleh siswa dengan baik. Selain itu dengan menggunakan modul berbasis kontekstual siswa mampu mengaitkan masalah sehari-hari dengan konsep matematika. Dengan menggunakan modul bercirikan kontekstual ini siswa dapat beraktifitas secara signifikan yang membantu mereka dalam menghubungkan studi akademik dengan konteks dalam situasi kehidupan nyata, artinya baik materi ataupun soal-soal di dalam modul yang dituliskan dikaitkan dengan kehidupan sehari-hari (Wulandari, 2012)

Berdasarkan hasil uji coba lapangan, modul kontekstual memiliki kelebihan dan kekurangan. Kelebihan modul kontekstual adalah: (1) Modul dapat digunakan sebagai sumber belajar siswa dalam pembelajaran berbasis kontekstual pada materi barisan dan deret, (2) modul disusun agar siswa dapat belajar mandiri, sehingga struktur modul disesuaikan dengan karakteristik siswa, (3) Modul disusun untuk membimbing siswa untuk mengkonstruksi pemahaman siswa terhadap materi yang disajikan, (4) Modul memberi ruang bagi siswa untuk menuangkan ide dan gagasannya dalam menyelesaikan masalah, (5) Modul memberi kesempatan kepada siswa untuk berlatih mengerjakan soal secara mandiri melalui soal latihan, maupun uji kompetensi. Berdasarkan hasil uji lapangan, peneliti menemukan beberapa catatan yang berkaitan dengan kelebihan dan kekurangan modul yang dikembangkan. Kelebihan modul yang dikembangkan adalah (1) modul dapat digunakan sebagai sumber belajar siswa dalam pembelajaran berbasis kontekstual pada materi barisan dan deret, (2) modul memberi kesempatan kepada siswa untuk berlatih mengerjakan soal secara mandiri melalui soal latihan, maupun uji kompetensi untuk belajar mandiri, (3) modul dapat membimbing siswa untuk mengkonstruksi pemahaman siswa terhadap materi yang disajikan dan (4) modul memberi ruang bagi siswa untuk menuangkan ide dan gagasannya dalam menyelesaikan masalah.

Selain kelebihan, modul juga memiliki kelemahan. Kelemahan modul yang disusun adalah (1) modul yang dikembangkan hanya berdasar pada analisis masalah pembelajaran dan analisis karakteristik siswa dalam pembelajaran matematika di SMK Negeri 2 Malang, sehingga modul tersebut hanya sesuai dengan karakteristik siswa SMK Negeri 2 malang atau untuk sekolah yang siswanya memiliki kondisi yang kondisinya setara dengan siswa SMK Negeri 2 Malang, (2) tidak semua siswa SMK memiliki motivasi tinggi untuk menyelesaikan modul, sehingga 
Jurnal Inspirasi Pendidikan

Universitas Kanjuruhan Malang

masih ada siswa yang tidak mampu menyelesaikan modul tepat waktu.

\section{KESIMPULAN DAN SARAN}

Modul yang dikembangkan merupakan modul kontekstual untuk siswa SMK kelas XI program pariwisata. Pengembangan modul bercirikan kon-tekstual dikembangkan menggunakan model Plomp 3 fase, yaitu (1) penelitian awal (preliminary research), (2) fase pengembangan (prototyping phase), dan (3) fase penilaian (assessment phase). Komponen-komponen yang tersedia dalam modul pembelajaran ini yaitu (a) bagian pendahuluan, (b) bagian Kegiatan Belajar, (c) Latihan, (d) Uji Kompetensi, (e) daftar pustaka dan (f) Glosarium. Berdasarkan hasil validasi, diperoleh skor rata-rata 3,58. Berdasarkan kriteria kevalidan, modul ini valid dan layak untuk digunakan dalam pembelajaran.

\section{DAFTAR PUSTAKA}

Danuri.2014. Pengembangan Modul Matematika dengan Pendekatan Kontekstual untuk Memfasilitasi Kemandirian Belajar Siswa SD/MI. Jurnal Al Bidayah, Vol.6 (1). Pp. 39-58. ISSN 2085-0034

Johnson, E. B, 2002. Contextual Teaching and Learning : What it is and why it is here to stay. California USA : Corwin Press. Inc

Plomp, T. 2010. Educational Design Research: An Introduction. Dalam Tjeerd P. \& Nienke, N. (Eds). An Introduction to Educational Design Research. Enschede: Netherlands Institute for Curriculum Development.

Sutama,dkk.2013. Pengelolaan Pembelajaran Matematika Kontekstual di
Sekolah Menengah Kejuruan. Delta jurnal.Vol. 1, No. 2, Juli 2013, hlm 115199

Suryaningsih, Y. 2011. Pengembangan Buku Peserta Didik Untuk Belajar Berbasis Masalah Pada Materi Prisma dan Limas di SMPN 1 Poncokusumo. Tesis, tidak dipublikasikan. Universitas Negeri Malang.

Wulandari, Tri C, 2012. Pengembangan Modul Bercirikan Kontekstual pada Pokok Bahasan Program Linier di SMK Negeri 2 Malang. Tesis, tidak dipublikasikan.Universitas Negeri Malang. 